\title{
Italian Volcanic lakes: a diversity hotspot and refuge for European charophytes
}

\author{
Mattia M. AZZELLA* \\ Department of Environmental Biology, La Sapienza University of Rome, p.le A. Moro 5, 00185 Rome, Italy \\ *Corresponding author: mattia.azzella@gmail.com
}

\begin{abstract}
Macrophytes are one of the most important components of primary producers in lacustrine environments. Charophytes represent the most threatened group of macrophytes and are included in many European Red-Lists. Thus, finding and preserving charophyte diversity hotspots is important for European macrophyte conservation strategies. Within the framework of a general project aimed at investigating aquatic plant diversity of Italian volcanic lakes (IVL), a field survey carried out in 2009-2010 recognized high charophyte diversity. Overall, 17 species of charophytes, which correspond to 50\% of Italian stoneworts and 30\% of the European species, were recorded. Nevertheless, only four IVL out of the nine lakes investigated can be considered Chara-dominated lakes. Three Chara-vegetation belts characterized the Chara dominated IVL, as in other pristine deep calcareous European lakes. A Chara aspera belt grew at a lower depth, followed by a Chara polyacantha belt at a medium depth and a Chara globularis dominated belt at a higher depth, up to the maximum growing depth. The most common species was Chara globularis, whereas seven species were rare. Sixteen of the 17 species found belong to the IUCN threatened categories throughout Europe. The most interesting taxa are Nitella hyalina, Nitella gracilis and Lychnothamnus barbatus. Nitella hyalina is extinct in Switzerland and Great Britain, critically endangered in the Balkans and in Germany. Nitella gracilis is extinct in Denmark and endangered in the Balkans, Sweden and Switzerland. The Lychnothamnus barbatus population found in Martignano is the only one known in Italy. Lakes Vico, Martignano, Bolsena and Bracciano host from 18\% to 44\% of European charophytes. The high number of species in each lake allows the selection of these lakes as European hotspots of charophyte diversity. Therefore, the IVL can be a reference system for the conservation of aquatic species that are typical of Italian and European deep lakes.
\end{abstract}

Key words: Freshwater conservation, Characeae, Lake Bracciano, Chara, Nitella.

Received: January 2014. Accepted: April 2014.

\section{INTRODUCTION}

Macrophytes are one of the most important primary producers in lacustrine environments and represent a key element of the aquatic ecosystems (Carpenter and Lodge, 1986). The decline in quality and functionality documented in the last two centuries (Sala et al., 2000; Dudgeon et al., 2006) has led to critical regime shifts in primary production, promoting phytoplankton at the expense of macrophytes (Scheffer et al., 2001; Sayer et al., 2010). Charophytes represent one of the most threatened groups of macrophytes (Baastrup-Spohr et al., 2013), and Charadominated vegetation is one of the habitats of community interest (Habitat Directive 92/43 EEC), owing to its endangered and jeopardized status throughout Europe.

Charophytes, which are green algae of Characeae family and include the genus of Chareae (Chara, Lamprothamnium, Nitellopsis, and Lychnothamnus) and Nitelleae tribes (Nitella and Tolypella), have long been considered the closest sister group to vascular plants (Karol et al., 2001). Recently other authors have reconsidered this proximity (Leliaert et al., 2012), though stoneworts are still clearly one of the most important primary producers in lakes, playing a central role in the control of nutrient availability (Kufel and Kufel, 2002;
Blindow et al., 2002, Rodrigo et al. 2007). Stoneworts display a high sensitivity to water pollution and eutrophication phenomena, and are the first to disappear at the occurrence of pollution (Blindow, 1992; Blindow et al., 2002). As human activities have threatened their habitat in the last 100 years (Goldin 2010, Baastrup-Spohr et al., 2013), stonewort numbers are declining across Europe and many Red Lists now include them (Stewart and Church, 1992). Their sensitivity to water pollution allows stoneworts to be used as biological indicators (Melzer, 1999), a role that has been emphasized in the recent years following implementation of the Water Framework Directive (WFD - EU 2000/60) (Stelzer et al., 2005; Pall and Moser, 2009). However, knowledge about stoneworts in Italy is still scarce and incomplete. Some authors described the Italian stonewort flora in the $19^{\text {th }}$ century and early $20^{\text {th }}$ century (Bazzichelli and Abdelahad, 2009 and references therein). Since then, no other authors have attempted to collect information on the overall distribution of stoneworts in Italy, with all the modern reports deriving from regional (Tomasella and Oriolo, 2006) or local studies (Bolpagni et al., 2013). Therefore, no updated assessment on the presence and distribution in Italy exists, and an Italian Red List of charophytes is consequently still lacking. The scanty Italian literature available on the con- 
servation status of freshwater habitats points to a strong decline in the presence and distribution of macrophytes (Bresciani et al., 2012), mainly due to intensive agriculture, industrialization and urbanization (Bolpagni et al., 2012). A comparable trend may be hypothesised for charophytes.

A recent study has shown that large, deep Italian volcanic lakes (IVL) can be classified as Chara-lakes sensu Alquist (1929) and Vestergaard and Sand-Jensen (2000a) (Azzella et al., 2013b). In this paper, I will focus on charophyte species of IVL to evaluate their role in the conservation of Italian and European charophyte species richness. The gathering of information on plant diversity and species distribution is necessary to preserve biodiversity (Jackson et al., 2009; Vellak et al., 2009). The Global Strategy for Plant Conservation (GSPC) stresses the need to protect at least $50 \%$ of areas that are of high conservation value for plant diversity at the local or national level (Blasi et al., 2011). Therefore, identifying lakes in which charophyte habitats are well preserved is essential to I) study ecosystem processes in a reference system and II) elaborate conservation policies and restoration actions for the implementation of GSPC, WFD and Habitat Directive (92/43 EEC). Moreover, the identification of lakes in which charophytes are well preserved may help to conserve such lakes because stoneworts could be collected and reintroduced in areas where they are locally extinct (Auderset Joye and Schwarzer, 2012).

\section{METHODS}

\section{Study area}

The IVL system (Fig. 1) contains $94 \%$ of the freshwater volume in central and southern Italy, $80 \%$ of the deep lake surfaces within the Mediterranean coastal region and $42 \%$ of the area occupied by deep lakes, as defined in accordance with the WFD (Mediterranean Intercalibration Group - GIG). According to the Italian hydroecoregion classification, which was developed together with the WFD (Law Decree 152/06), most IVL belong to the Roma Viterbese hydroecoregion (i.e., coastal region, from the south of Tuscany to Rome), with only two lakes, i.e., Lago Grande and Lago Piccolo (Laghi di Monticchio), belonging to the hydroecoregion Appennino Meridionale (i.e., inner region in the southern part of the Apennines). Despite the limnological similarities with the Alpine lakes, Buraschi et al. (2005) classified IVL in a separate category (M7 - Mediterranean lakes of volcanic origin and with a mean depth greater than $15 \mathrm{~m})$. According to the Italian macroclimate classification (Blasi and Frondoni, 2011), most volcanic lakes belong to the temperate regions, with the exception of the lakes Bracciano and Martignano, which belong to the Mediterranean region.

\section{Sampling methods}

The floristic data in this study were collected during the 2009 and 2010 growing seasons (July-September) using two different methods of sampling, i.e., a phytolittoral inventory (Kanninen et al., 2013) in 2009, and the macrophyte survey method developed to analyze deep circular-shaped lakes in 2010 (Azzella et al., 2013b). Briefly, in 2010 a representative number of transects were selected for each lake. Then, data on macrophyte species occurrence and abundance were collected from each 1$\mathrm{m}$ depth interval up to the maximum colonization depth along the depth gradient. The nomenclature of charophytes follows Bazzichelli and Abdelahad (2009). Data collected in 2010 were used to evaluate the abundance of species in each lake. Water samples were collected in the winter and summer of 2010 to assess the chemical characteristics of IVL (Tab. 1). Water samples were collected in the center of the lakes, at five different depths on the water column. For each column, 3 samples were collected above the summer thermocline and 2 below it. Temperature, conductivity and $\mathrm{pH}$ were measured with a portable $\mathrm{pH} / \mathrm{EC} / \mathrm{TDS}$ meter (Hanna Instruments 9810)

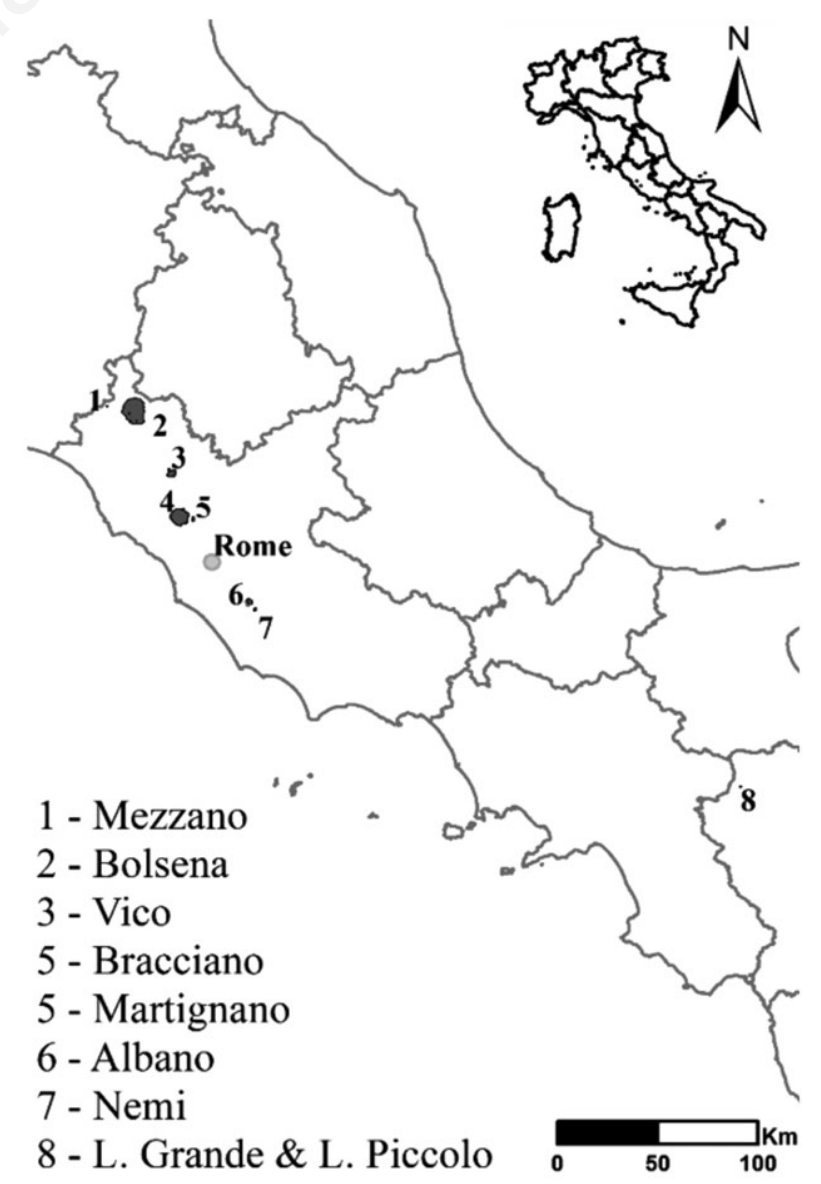

Fig. 1. Study area. The Italian volcanic lakes system. 
and water samples were stored and subsequently analyzed using standardized techniques (analysis methods in Legnani et al. 2005) to measure total phosphorus (TP), total nitrogen (TN) and alkalinity (Alk). CNR-IRSA (Centro Nazionale Ricerche - Istituto di Ricerca sulle Acque) laboratories performed the analyses.

\section{Analysis methods}

The data collected did not allow the in-lake relationship between ecological gradients and stoneworts to be assessed because they were not collected in the sampling stations along the depth gradient. Nevertheless, the correlation between winter chemical characteristics and the lakes' morphological characteristics and some stoneworts indices were calculated. Spearman's rank correlation coefficient was used to test the significance of the association between stonewort indices and the lakes' characteristics. Three stonewort indices were evaluated in the nine IVL: i) the stonewort maximum growing depth $\left(\mathrm{Zc}_{\mathrm{ch}}\right)$, a very common index used to assess water conservation status in relation to the Secchi disk (SD) (Søndergaard et al., 2013; Azzella et al. 2014a); ii) the ratio between stonewort abundance and vascular plants abundance (C/VP), to verify the hypothesis that higher nutrient concentrations imply a higher abundance of vascular plants and a lower abundance of charophytes (Vestergaard and Sand-Jensen 2000a); iii) the number of stonewort species (Nch) was tested in relation to the lakes' area (Ar) to verify whether the bigger lakes host a higher number of charophytes (Rørslett 1991, Vestergaard and SandJensen 2000b). All the analyses were performed using PAST 3.01 (Hammer et al., 2001).

Originally, Myers (1988) defined biodiversity hotspots as: areas featuring exceptional concentrations of endemic species and experiencing exceptional loss of habitat. However, most authors currently use a simplify definition, based on the presence of a particularly high species rich- ness or the high frequency of rare species (Reid 1998). The rarity of the species was evaluated by using the number of sampling stations in which the species were found. In the present work a species is defined rare when it was found fewer than 10 times, and very rare when it was found only once. On the other hand, the stoneworts found in at least 100 sampling stations were classified as very common species, stoneworts found between 50 and 100 times as common species, and stoneworts found between 10 and 50 times as fairly common species.

To evaluate the conservation value of IVL and determine whether they could be considered as diversity hotspots and refuges for European charophytes, I refer to the red data list of charophytes in the Balkans (Blaženčić et al., 2006), where lakes that host more than $18 \%$ of European charophyte species were considered a hotspot.

\section{RESULTS AND DISCUSSION}

Globally, 17 taxa of stoneworts were identified (11 species of the genus Chara, four species of the genus Nitella, one species of Nitellopsis and one species of $L y$ chnotamnus) (Tab. 2). If we consider that there are a total of 54 charophyte species in Europe (Krause, 1997) and 32 species in Italy (Bazzichelli and Abdelahad, 2009), IVL host more than $50 \%$ of the Italian species and about $30 \%$ of the European charophyte species. Lakes Bolsena, Bracciano, Martignano and Vico contain large submerged stonewort beds (Fig. 2). Lakes Bracciano and Bolsena host the highest number of species (16 and 14 species, respectively) (Tab. 2). This finding is compatible with the hypothesis that larger lakes host higher numbers of stonewort species, as is also suggested by the fact that the Nch is significantly higher in IVL with higher Ar (Spearman $\mathrm{rs}=0.96, \mathrm{P}<0.001$ ).

The most common species in IVL was Chara globularis, which was present in all the lakes and was recorded in more than 100 sampling stations (Tab. 2), while four

Tab. 1. Morphometric characteristics and hydrochemical features of Italian volcanic lakes.

\begin{tabular}{|c|c|c|c|c|c|c|c|c|c|c|}
\hline Lake & $\begin{array}{l}\mathrm{Ar}^{*} \\
\mathrm{~km}^{2}\end{array}$ & $\begin{array}{l}\mathrm{Al}^{*} \\
\mathrm{~m} \text { asl }\end{array}$ & $\begin{array}{c}\mathrm{Md}^{*} \\
\mathrm{~m}\end{array}$ & $\begin{array}{c}\mathrm{V}^{*} \\
\mathrm{~m}^{3} 10^{6}\end{array}$ & $\begin{array}{c}\text { Alk } \\
\mathrm{m}^{2} \mathrm{~L}^{-1}\end{array}$ & $\begin{array}{c}\text { Cond } \\
\mu \mathrm{S} \mathrm{cm}^{-1} 20^{\circ} \mathrm{C}\end{array}$ & $\mathrm{pH}$ & $\begin{array}{c}\mathrm{TP} \\
\mu \mathrm{g} \mathrm{L}^{-1}\end{array}$ & $\begin{array}{c}\mathrm{TN} \\
\mathrm{mg} \mathrm{L}^{-1}\end{array}$ & $\begin{array}{c}\mathrm{SD} \\
\mathrm{m}\end{array}$ \\
\hline Albano & 6.0 & 293 & 170 & 464.3 & 3.6 & 302 & 8.7 & 21.6 & 0.3 & 5.2 \\
\hline Bolsena & 114.5 & 305 & 146 & 8922.0 & 4.1 & 494 & 8.1 & 17.2 & 0.3 & 12.0 \\
\hline Bracciano & 57.5 & 164 & 160 & 4950.0 & 3.2 & 482 & 8.0 & 14.2 & 0.2 & 13.5 \\
\hline Lago Grande & 0.4 & 656 & 35 & 3.4 & 3.4 & 398 & 7.4 & 123.6 & 1.7 & 1.2 \\
\hline Lago Piccolo & 0.2 & 658 & 38 & 38.0 & 3.1 & 318 & 7.7 & 24.1 & 3.7 & 2.3 \\
\hline Martignano & 2.5 & 207 & 54 & 71.2 & 2.7 & 373 & 7.5 & 11.4 & 0.3 & 4.5 \\
\hline Mezzano & 0.5 & 455 & 31 & 8.1 & 1.4 & 179 & 7.6 & 22.0 & 0.6 & 2.5 \\
\hline Nemi & 1.7 & 318 & 34 & 32.5 & 2.3 & 190 & 8.8 & 34.0 & 0.6 & 5.0 \\
\hline Vico & 12.1 & 507 & 50 & 268.0 & 2.4 & 401 & 8.0 & 22.1 & 0.4 & 2.5 \\
\hline
\end{tabular}

Ar, area; Al, altitude; $M d$, max depth; $V$, volume; Alk, alkalinity; Cond, conductivity; TP, total phosphorus; TN, total nitrogen; SD, Secchi disk. "Data from Tartari et al., 2004. 
Tab. 2. Presence of stoneworts in the Italian volcanic lakes and rarity of the species.

\begin{tabular}{|c|c|c|c|c|c|c|c|c|}
\hline & Bracciano & Bolsena & Vico & Martignano & Albano & Mezzano & Nemi & FQR \\
\hline Chara globularis Thuillier & $\checkmark$ & $\checkmark$ & $\checkmark$ & $\checkmark$ & $\checkmark$ & $\checkmark$ & $\checkmark$ & ++ \\
\hline Nitellopsis obtusa (Desv. in Lois) J. Gr. & $\checkmark$ & $\checkmark$ & $\checkmark$ & $\checkmark$ & & $\checkmark$ & $\checkmark$ & ++ \\
\hline Chara aspera Detharding ex Wildenow & $\checkmark$ & $\checkmark$ & $\checkmark$ & $\checkmark$ & $\checkmark$ & & & ++ \\
\hline Chara hispida L. sensuauct. nonnull. & $\checkmark$ & $\checkmark$ & $\checkmark$ & $\checkmark$ & $\checkmark$ & & & $* * *$ \\
\hline Chara vulgaris Linnaeus & $\checkmark$ & $\checkmark$ & $\checkmark$ & $\checkmark$ & $\checkmark$ & & & $* * *$ \\
\hline Nitella hyalina (de Candolle) C. Agardh & $\checkmark$ & $\checkmark$ & $\checkmark$ & $\checkmark$ & $\checkmark$ & & & + \\
\hline Chara intermedia A. Braun & $\checkmark$ & $\checkmark$ & $\checkmark$ & $\checkmark$ & & & & + \\
\hline Chara polyacantha A. Braun in Br.,Rab. \& Sti. & $\checkmark$ & $\checkmark$ & $\checkmark$ & $\checkmark$ & & & & ++ \\
\hline Chara tomentosa Linnaeus & $\checkmark$ & $\checkmark$ & $\checkmark$ & $\checkmark$ & & & & ++ \\
\hline Chara delicatula C. Agardh & $\checkmark$ & $\checkmark$ & $\checkmark$ & & & & & $* *$ \\
\hline Nitella gracilis (Smith) C. Agardh & $\checkmark$ & $\checkmark$ & $\checkmark$ & & & & & $* *$ \\
\hline Nitella opaca (C. Agardh ex Bruzelius) C. Agardh & $\checkmark$ & $\checkmark$ & & $\checkmark$ & & & & ++ \\
\hline Nitella tenuissima (Desvaux) Kutzing & $\checkmark$ & $\checkmark$ & $\checkmark$ & & & & & $* *$ \\
\hline Chara gymnophylla A. Braun & $\checkmark$ & $\checkmark$ & & & & & & $* *$ \\
\hline Chara crassicaulis $\mathrm{S}$. chleicher & $\checkmark$ & & & & & & & * \\
\hline Chara contraria A. Braun ex Kützing & $\checkmark$ & & & & & & & * \\
\hline Lychnothamnus barbatus (Meyen) Leonh. & & & & $\checkmark$ & & & & * \\
\hline
\end{tabular}

${ }^{*} F Q R$, rarity of the species; * very rare species (only one sampling station); **rare species (fewer than 10 sampling stations); ***fairly common (between 10 and 50 sampling stations); +, common species (between 50 and 100); ++, very common species (more than 100).

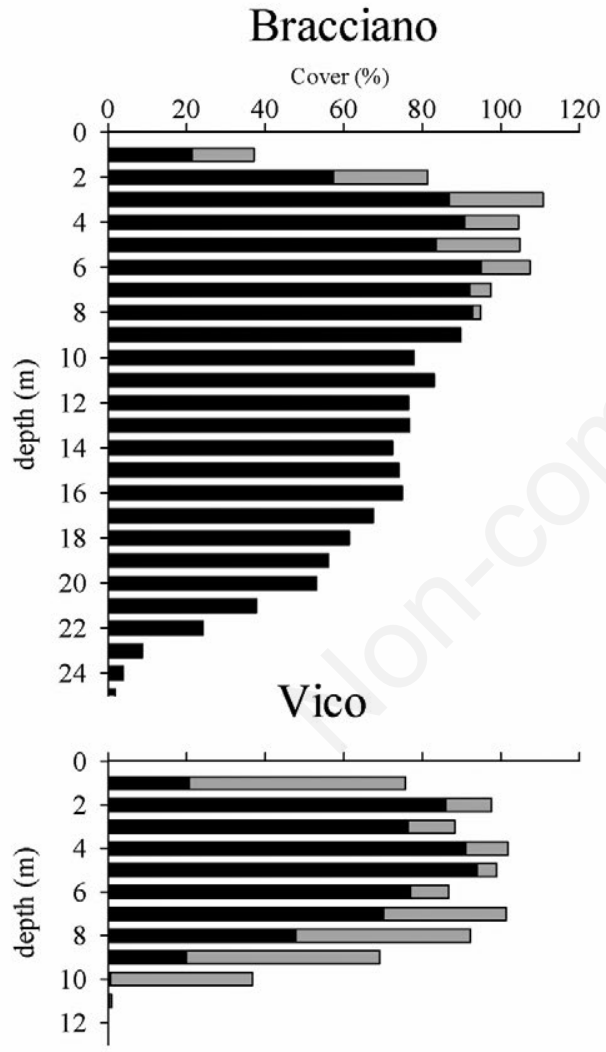

Mezzano

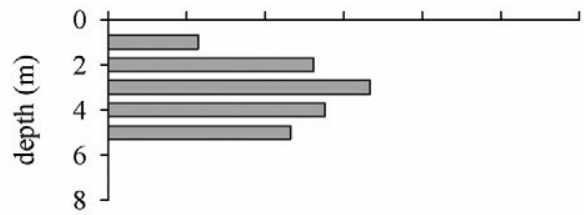

Bolsena

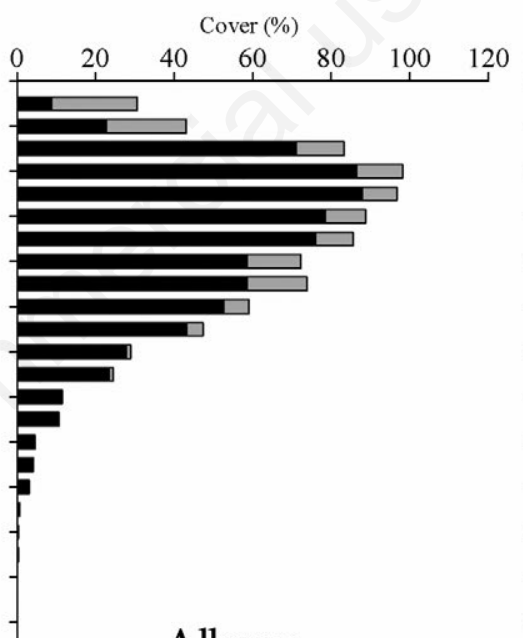

Albano

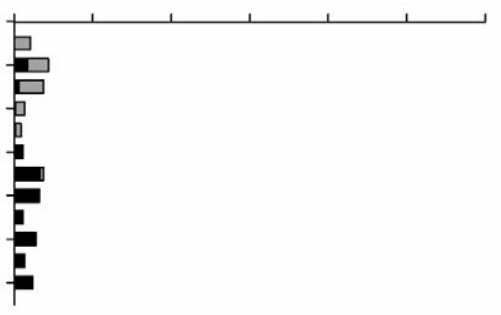

Lago Piccolo

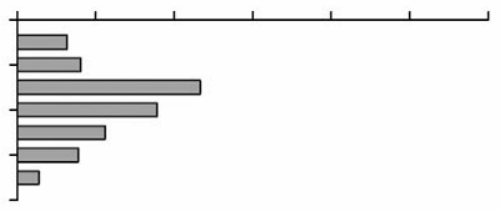

Martignano

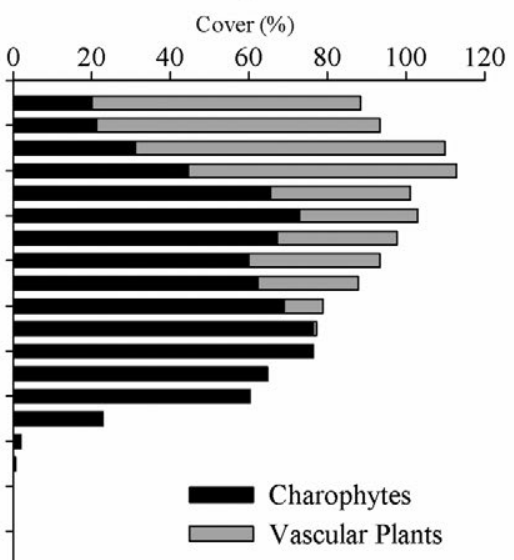

Nemi

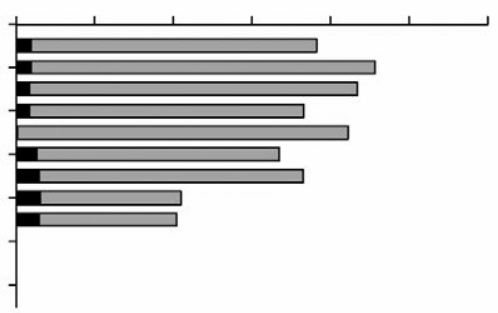

Lago Grande

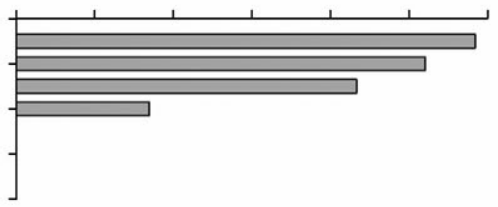

Fig. 2. Macrophyte cover in Italian volcanic lakes. Four lakes are Chara-dominated lakes, with a high percentage of charophyte cover (black). The last four lakes are dominated by vascular plants (grey). 
species were rare (Chara delicatula, C. gymnophylla, Nitella gracilis and $N$. tenuissima, which were found fewer than 10 times) and three were very rare (Lychnothamnus barbatus, Chara crassicaulis and C. contraria, which were found only once). Lakes Albano, Nemi and Mezzano displayed a low number of charophytes, while no species were found in Lake Grande and Lake Piccolo. Although historical information about IVL is scant (Azzella et al., 2014b), there are reports on the historical presence of Nitellopsis obtusa populations in Lake Grande (Trotter, 1908) and of Chara-dominated belts down to 12 meters of depth in Albano (Stella, 1951). Re- cently, other studies have reported the recovery and the appearance of charophytes in Nemi, i.e. a lake in which they had not previously been recorded (Mastrantuono and Sforza, 2008; Azzella et al., 2014b). Thus, the absence of stoneworts in some lakes and the low cover values in other lakes may be the result of recent human impacts.

Chara polyacantha dominated the aquatic vegetation in Bracciano and Martignano. Chara tomentosa yielded its highest value of abundance in Lake Bolsena, while Nitellopsis obtusa was most abundant in Lake Vico. The species abundance gradient along depth showed similar patterns in the four Chara-dominated lakes (Fig. 3). Recently, follow-
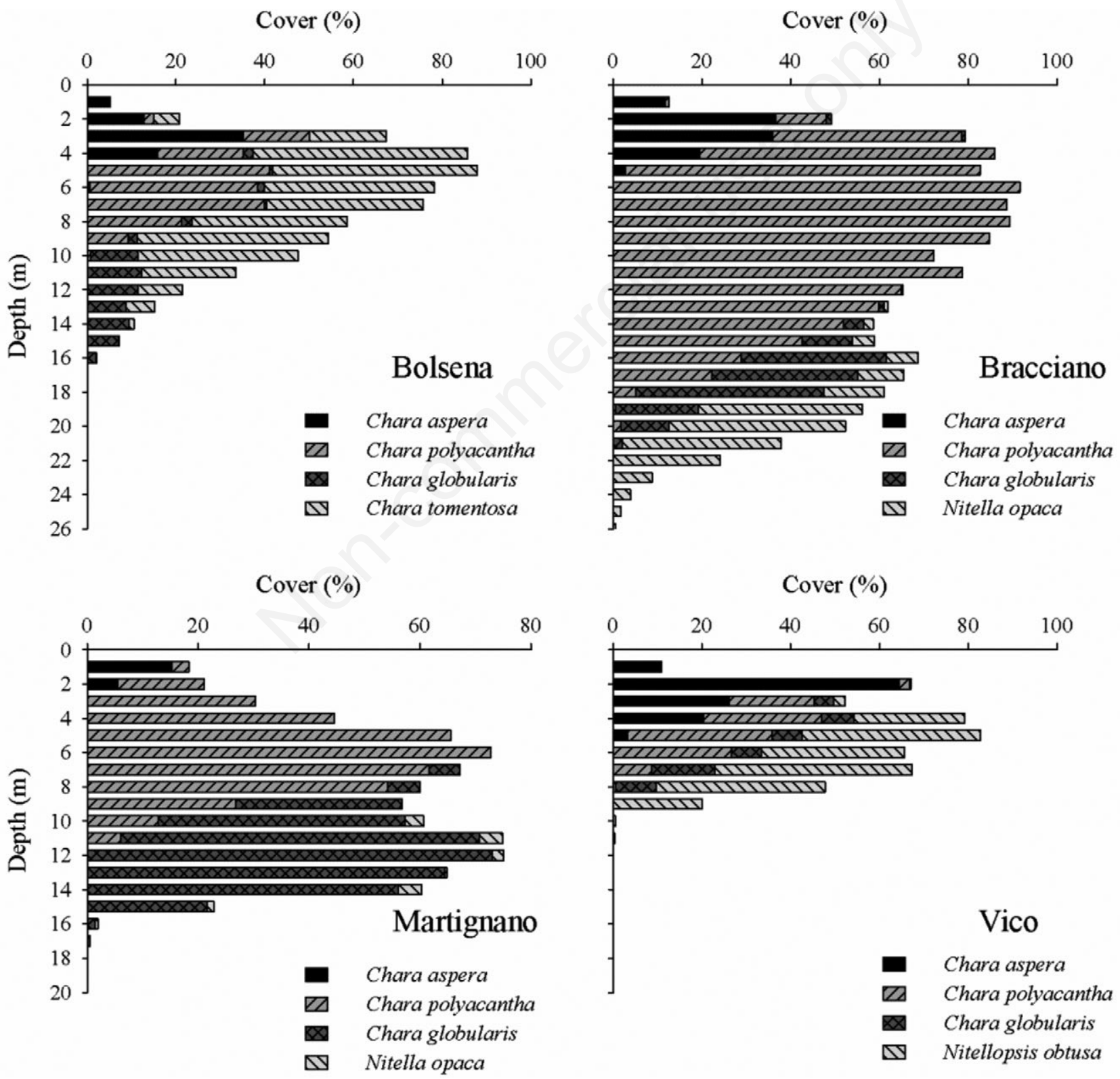

Fig. 3. Distribution of the four most abundant stonewort species in the Chara-dominated Italian volcanic lakes. 
ing the implementation of the Water Framework Directive (EU/2000/60), Pall and Moser (2009) created a multimetric index based on aquatic plants, the Austrian Index Macrophyte (AIM). One of the metrics of the AIM is characteristic zonation, which assigns considerable importance to the presence of three different Chara-dominated vegetation belts in pristine lakes. Other authors found this characteristic zonation in Lake Garda (Bolpagni et al., 2013). Similar conditions were found in IVL, with typical Chara-dominated vegetation belts (Fig. 3): a Chara aspera belt at lower depth, followed by a Chara polyacantha belt at medium depth and a Chara globularis dominated belt at higher depth. This pattern is evident in Lakes Bracciano and Martignano, where TP and TN values were lowest (Tab. 1). Some differences emerged in the characteristic zonation of Bolsena, where Chara tomentosa is the dominant species, followed by a marked presence of Chara polyacantha, as well as in that of Vico, where Nitellopsis obtusa and Chara polyacantha co-dominate. Four belts were identified in Bracciano in 2010, probably as a result of the very high Secchi disk value. The last belt reached 26 meters of depth and was dominated by Nitella opaca. Although this depth is impressive, it is not the highest ever reported for this species. Indeed, a maximum growing depth of 37 meters for Nitella opaca has previously been reported in Lake Vrana (Golubić, 1963), of 33 meters in Lake Thingvallavatn (Kairesalo et al. 1992) and of 27 meters in Lake Towada (Jimbo et al., 1955). In IVL, Nitella opaca and Chara globularis were the commonest species at high depths, as is generally reported in the northern hemisphere (Kairesalo et al., 1992; Frantz and Cordone, 1967). The analyses of the selected indices showed that the $\mathrm{Zc}_{\mathrm{ch}}$ is significantly higher in lakes with a higher SD (Spearman $\mathrm{rs}=0.89, \mathrm{P}<0.01)$ and lower TP $($ Spearman $\mathrm{rs}=-$ $0.85, \mathrm{P}<0.01)$ and TN (Spearman $\mathrm{rs}=-0.98, \mathrm{P}<0.01)$ values, while the C/VP ratio was significantly higher in lakes with a lower TP (Spearman $\mathrm{rs}=0.69, \mathrm{P}<0.05)$ and TN (Spearman $\mathrm{rs}=-0.91, \mathrm{P}<0.01$ ). These findings thus confirm

Tab. 3. Risk status of the Italian volcanic lakes' charophyte species in the European red lists. The red lists from the Balkans to Hungary use IUCN categories (IUCN, 2001).

\begin{tabular}{|c|c|c|c|c|c|c|c|c|c|c|c|c|}
\hline & Balkans & Sweden & Switzerland & Norway & $\begin{array}{c}\text { Great } \\
\text { Britain }\end{array}$ & Finland & Bulgaria & Hungary & Germany & Denmark & Poland & $\begin{array}{c}\text { Czech } \\
\text { Republic }\end{array}$ \\
\hline Chara aspera & LR & & VU & NT & & & DD & & 3 & & $\mathrm{E}$ & $\mathrm{HE}$ \\
\hline Chara contraria & LR & & $\mathrm{LC}$ & VU & & $\mathrm{CR}$ & VU & & $*$ & & $\mathrm{~V}$ & \\
\hline Chara delicatula & & & VU & & & & VU & & $*$ & & V & $\mathrm{HE}$ \\
\hline Chara gymnophylla & & & & & & & & & & & & $\mathrm{CE}$ \\
\hline Chara globularis & LR & & $\mathrm{LC}$ & & & & & VU & $*$ & & $\mathrm{~V}$ & $\mathrm{CS}$ \\
\hline Chara hispida & VU & & VU & NT & & & DD & VU & 3 & & $\mathrm{E}$ & ES \\
\hline Chara intermedia & $\mathrm{EN}$ & & EN & NT & EN & NT & & & 3 & TE & & VS \\
\hline Chara polyacantha & EN & NT & $\mathrm{CR}$ & EN & & & & & 3 & ER & $\mathrm{E}$ & VS \\
\hline Chara tomentosa & VU & & VU & $\mathrm{CR}$ & & & DD & & 3 & $\mathrm{R}$ & $\mathrm{R}$ & VS \\
\hline Chara vulgaris & LR & & VU & EN & & & & LR & $*$ & & V & $\mathrm{CS}$ \\
\hline Lychnothamnus barbatus & EN & & & & & & & & 2 & & $\mathrm{E}$ & \\
\hline Nitella gracilis & EN & NT & EN & VU & VU & VU & NT & & 2 & $\mathrm{RE}$ & I & $\mathrm{HE}$ \\
\hline Nitella hyalina & $\mathrm{CR}$ & & $\mathrm{RE}$ & & $\mathrm{RE}$ & VU & & & 1 & & & \\
\hline Nitella opaca & LR & & VU & & & & $\mathrm{RE}$ & & 3 & $\mathrm{TE}$ & I & ES \\
\hline Nitella tenuissima & VU & $\mathrm{RE}$ & $\mathrm{CR}$ & & $\mathrm{EN}$ & & DD & & 3 & & I & VS \\
\hline Nitellopsis obtusa & VU & VU & NT & & VU & VU & VU & EN & * & & $\mathrm{R}$ & VS \\
\hline
\end{tabular}

$R E$, extinct at the national level; $C R$, critically endangered; $E N$, endangered; $V U$, vulnerable; $N T$, near threatened; LR, low risk; LC, least concern; $D D$, data deficient. The last 4 lists (from Germany to the Czech Republic) use different codes. Germany: *ungefährdet (no risk); 1, vom Aussterben bedroht (critically endangered); 2, stark gefährdet (endangered); 3, gefährdet (vulnerable). Denmark: RE, extinct at the national level; TE, threatened by extinction; $R$, rare; ER, extremely rare. Poland: E, critically endangered; V, vulnerable; $R$, rare; ER, extremely rare; I, data deficient. Czech Republic: VS, vanishing species; CE: critically endangered; HE, highly endangered; ES, endangered species; CS, common species. Data References: Blaženčic et al., 2006 (Balkans. Balkans included Serbia \& Montenegro, Croatia, Macedonia, Slovenia, Bosnia \& Herzegovina, Bulgaria, Romania, Greece, Albania), Gärdenfors, 2010 (Sweden), Auderset Joye and Schwarzer, 2012 (Switzerland), Kålås et al., 2010 (Norway), Stewart and Church, 1992 (Great Britain), Koistinen, 2010 (Finland), Temniskova et al., 2008 (Bulgaria), Németh, 2005 (Hungary), Korsch et al., 2012 (Germany), Baastrup-Spohr et al., 2013 (Denmark), Siemińska et al., 2006 (Poland), Caisová and Gąbka, 2009 (Czech Republic). 
the hypothesis that charophyte communities need transparent water with low TP and TN concentrations to colonize lakes at great depth, and that the higher the phosphorus and nitrogen concentrations, the lower the charophyte abundance.

Out of the 17 species found, 16 species belong to the IUCN threatened categories throughout Europe (Tab. 3). In particular, Nitella hyalina, which is a common species in IVL, is extinct in Switzerland and Great Britain, and critically endangered in the Balkans and in Germany. Nitella gracilis is extinct in Denmark and endangered in the Balkans, Sweden and Switzerland. The Lychnothamnus barbatus population found in Lake Martignano is the only one known in Italy (Azzella and Abdelahad, 2011). Chara polyacantha and C. tomentosa, the most abundant species in Lakes Bracciano and Bolsena, are included in many European red lists. Blaženčić et al. (2006) identified four Balkan lakes as hot-spots and potential centers of diversity of charophytes in the Balkan Peninsula. The lakes identified as hotspots host from $19 \%$ to $51 \%$ of the total stonewort species found in the Balkans and from $18 \%$ to $44 \%$ of the European charophytes. Four IVL host more than $19 \%$ of the total Italian stonewort flora and more than $18 \%$ of the European stonewort flora. These lakes (Bolsena, Bracciano, Martignano and Vico) may be considered as hotspots and centers of charophyte diversity at both the national and European levels. Furthermore, these lakes fulfill all three criteria required to be considered as Important Plant Areas (Marignani and Blasi, 2013). Lake Bracciano hosts the largest number of stoneworts and many interesting and endemic vascular macrophytes (Troia and Azzella, 2013). It may, therefore, serve as a reference system for the conservation of aquatic species typical of Italian and European deep lakes. Moreover, the similarities in the distribution of charophyte vegetation between IVL and Lake Garda and Austrian limestone foothill lakes suggest that the vegetation across European deep lakes is to some extent shared. These common characteristics might allow the implementation of the WFD to be coordinated, thereby obviating the need for a distinction between intercalibration groups (GIG) for macrophytes. The presence of negative trends highlighted in the flora (Azzella et al., 2014b) and vegetation (Azzella et al., 2013a) of IVL highlights the need for monitoring programs to protect these important ecosystems.

\section{CONCLUSIONS}

The Italian Volcanic Lakes system is a strategic reserve of freshwater that is threatened by over-exploitation owing to the potential economic value it represents. The biggest lakes within the system (Lakes Bolsena, Bracciano, Vico and Martignano) host an extraordinary number of freshwater macro algae of the Characeae family, which are critically endangered throughout Europe.
Therefore, these lakes may be considered a European hotspot of charophyte biodiversity and should be included in the Italian Important Plant Areas. An increase in the level of human pressure as well as climate change might affect these hotspots.

One future challenge will be to maintain the correct balance between the environment and human interests, according to the management polices recommended by the Global Strategy for Plant Conservation and the Water Framework Directive.

\section{ACKNOWLEDGMENTS}

I would like to thanks Nadia Abdelahad for the useful comments and the help she gave me in the last few years.

\section{REFERENCES}

Almquist E, 1929. [Upplands vegetation och flora].[Book in Swedish]. Almqvist \& Wiksells: 624 pp.

Auderset Joye D, Schwarzer A, 2012. [Lista Rossa Caracee. Specie minacciate in Svizzera, stato 2010, p. 72].[Book in Italian]. In: 1213, P.a.n. (ed.). Ufficio federale dell'ambiente, Berna, e Laboratoire d'Ecologie et de Biologie Aquatique dell'Università di Ginevra.

Azzella MM, Abdelahad N, 2011. [Une station actuelle de Lychnothamnus barbatus (Charophyceae) en Italie Centrale: le Lac de Martignano (Latium)].[Article in French]. Cryptogamie Algol. 32:301-307.

Azzella MM, Bolpagni R, Oggioni A, 2014a. A preliminary evaluation of lake morphometric traits influence on the maximum colonization depth of aquatic plants. J. Limnol. 73:400-406.

Azzella MM, Iberite M, Fascetti S, Rosati L, 2013a. Loss detection of aquatic habitats in Italian volcanic lakes using historical data. Plant Biosyst. 147:521-524.

Azzella MM, Ricotta C, Blasi C, 2013b. Aquatic macrophyte diversity assessment: validation of a new sampling method for circular-shaped lakes. Limnologica 43:492-499.

Azzella MM, Rosati L, Iberite M, Bolpagni R, Blasi C, 2014b. Changes in aquatic plants in the Italian volcanic-lake system detected using current data and historical records. Aquat. Bot. 112:41-47.

Baastrup-Spohr L, Iversen LL, Dahl-Nielsen J, Sand-Jensen K, 2013. Seventy years of changes in the abundance of Danish charophytes. Freshwater Biol. 58:1682-1693.

Bazzichelli G, Abdelahad N, 2009. [Flora analitica delle Caroficee].[Book in Italian]. La Sapienza University of Rome: $80 \mathrm{pp}$.

Blasi C, Frondoni R, 2011. Modern perspectives for plant sociology: the case of ecological land classification and the ecoregions of Italy. Plant Biosyst. 145:30-37.

Blasi C, Marignani M, Copiz R, Fipaldini M, Bonacquisti S, Del Vico E, Rosati L, Zavattero L, 2011. Important plant areas in Italy: from data to mapping. Biol. Conserv. 144:220-226.

Blaženčić J, Stevanović B, Blaženčić Z, Stevanović V, 2006. Red data list of charophytes in the Balkans. Biodivers. Conserv. 15:3445-3457.

Blindow I, 1992. Decline of charophytes during eutrophication: 
comparison with angiosperms. Freshwater Biol. 28:9-14.

Blindow I, Hargeby A, Andersson G, 2002. Seasonal changes of mechanisms maintaining clear water in a shallow lake with abundant Chara vegetation. Aquat. Bot. 72:315-334.

Bolpagni R, Bartoli M, Viaroli P, 2012. Species and functional plant diversity in a heavily impacted riverscape: implications for threatened hydro-hygrophilous flora conservation. Limnologica 43:230-238.

Bolpagni R, Bettoni E, Bonomi F, Bresciani M, Caraffini K, Costaraoss S, Giacomazzi F, Monauni C, Montanari P, Mosconi MC, 2013. Charophytes of the lake Garda (Northern Italy): a preliminary assessment of diversity and distribution. J. Limnol. 72:388-393.

Bresciani M, Bolpagni R, Braga F, Oggioni A, Giardino C, 2012. Retrospective assessment of macrophytic communities in southern Lake Garda (Italy) from in situ and MIVIS (Multispectral Infrared and Visible Imaging Spectrometer) data. J. Limnol. 71:180-190.

Buraschi E, Salerno F, Monguzzi C, Barbiero G, Tartari G, 2005. Characterization of the Italian lake-types and identification of their reference sites using anthropogenic pressure factors. J. Limnol. 64:75-84.

Caisová L, Gąbka M, 2009. Charophytes (Characeae, Charophyta) in the Czech Republic: taxonomy, autecology and distribution. Fottea 9:1-43.

Carpenter SR, Lodge DM, 1986. Effects of submersed macrophytes on ecosystem processes. Aquat. Bot. 26:341-370.

Dudgeon D, Arthington AH, Gessner MO, Kawabata ZI, Knowler DJ, Leveque C, Naiman RJ, Prieur-Richard AH, Soto D, Stiassny MLJ, Sullivan CA, 2006. Freshwater biodiversity: importance, threats, status and conservation challenges. Biol. Rev. 81:163-182.

Frantz TC, Cordone AJ, 1967. Observations on deepwater plants in Lake Tahoe, California and Nevada. Ecology 48:710-714.

Gärdenfors U, 2010. [The 2010 Red List of Swedish species].[Book in Swedish]. Artdatabanken, SLU, Uppsala.

Goldyn H, 2010. Changes in plant species diversity of aquatic ecosystems in the agricultural landscape in West Poland in the last 30 years. Biodivers. Conserv. 19:61-80.

Golubić S, 1963. [Hydrostatischer Druck, Licht und submerse Vegetation im Vrana-See].[Article in German]. Int. Rev. Ges. Hydrobiol. Hydrogr. 48:1-7.

Hammer Ø, Harper DA, Ryan PD, 2001. PAST: Paleontological statistics software package for education and data analysis. Palaeontol. Electronica 4:9.

Jackson SF, Walker K, Gaston KJ, 2009. Relationship between distributions of threatened plants and protected areas in Britain. Biol. Conserv. 142:515-1522.

Jimbo T, Takamatsu M, Kuraishi H, 1955. Notes on the aquatic vegetation of Lake Towada. Ecol. Rev. 14:1-9.

Kairesalo T, St. Jonsson G, Gunnarsson K, Lindegaard C, Jonasson PM, 1992. Metabolism and community dynamics within Nitella opaca (Charophyceae) beds in Thingvallavatn. Oikos 64:241-256.

Kålås J, Viken Å, Henriksen S, Skjelseth S, 2010. [The 2010 Norwegian red list for species].[Book in Norwegian]. Norwegian Biodiversity Information Centre, Trondheim.

Kanninen A, Vallinkoski VM, Leka J, Marjomäkia T, Hellsten S, Hämäläinena H, 2013. A comparison of two methods for surveying aquatic macrophyte communities in boreal lakes: implications for bioassessment. Aquat. Bot. 104:88-100.

Karol KG, McCourt RM, Cimino MT, Delwiche CF, 2001. The closest living relatives of land plants. Science 294:2351-2353.

Koistinen M, 2010. [Näkinpartaislevät - Stoneworts Characeae, p. 204-207]. In: P. Rassi, E. Hyvärinen, A. Juslén and I. Mannerkoski (eds.), [The 2010 Red List of Finnish Species].[Book in Finnish]. Helsinki.

Korsch H, Doege A, Rraabe U, van de Weyer K, 2012. [Rote Liste der Armleuchteralgen (Charophyceae) Deutschlands]. [Haussknechtia Beiheft 17:1-32.

Krause W, 1997. Charales (Charophyceae). Gustav Fischer Verlag: 202 pp.

Kufel L, Kufel I, 2002. Chara beds acting as nutrient sinks in shallow lakes - a review. Aquat. Bot. 72:249-260.

Legnani E, Copetti D, Oggioni A, Tartari G, Palumbo MT, Morabito G, 2005. Planktothrix rubescens' seasonal dynamics and vertical distribution in Lake Pusiano (North Italy). J. Limnol. 64:61-73.

Leliaert F, Smith DR, Moreau H, Herron MD, Verbruggen H, Delwiche CF, De Clerck O, 2012. Phylogeny and molecular evolution of the green algae. Crit. Rev. Plant Sci. 31:1-46.

Marignani M, Blasi C, 2012. Looking for important plant areas: selection based on criteria, complementarity, or both? Biodivers. Conserv. 21:1853-1864.

Mastrantuono L, Sforza M, 2008. Recovery assessment in Lake Nemi (Italy) after a twenty year period (1981-2001) using plant-associated invertebrates. Aquat. Ecosyst. Health Manag. 11:310-320.

Melzer A, 1999. Aquatic macrophytes as tools for lake management. Hydrobiologia 395:181-190.

Myers N, 1988. Threatened biotas: hotspots in tropical forests. Environmentalist 8: 187-208.

Németh J, 2005. Red list of algae in Hungary. Acta Bot. Hung. 47:379-417.

Pall K, Moser V, 2009. Austrian Index Macrophytes (AIM-Module 1) for lakes: a Water Framework Directive compliant assessment system for lakes using aquatic macrophytes. Hydrobiologia 633:83-104.

Reid WV, 1998. Biodiversity hotspots. Trends Ecol. Evol. 13:275-280.

Rodrigo MA, Rojo C, Alvarez-Cobelas M, Cirujano S, 2007. Chara hispida beds as a sink of nitrogen: Evidence from growth, nitrogen uptake and decomposition. Aquat. Bot. 87:7-14.

Rørslett B, 1991. Principal determinants of aquatic macrophyte richness in northern European lakes. Aquat. Bot. 39:173-193.

Sala OE, Chapin FS, Armesto JJ, Berlow E, Bloomfield J, Dirzo R, Huber-Sanwald E, Huenneke LF, Jackson RB, Kinzig A, Leemans R, Lodge DM, Mooney HA, Oesterheld M, Poff NL, Sykes MT, Walker BH, Walker M, Wall DH, 2000. Biodiversity - Global biodiversity scenarios for the year 2100 . Science 287:1770-1774.

Sayer CD, Burgess A, Kari K, Davidson TA, Peglar S, Yang HD, Rose N, 2010. Long-term dynamics of submerged macrophytes and algae in a small and shallow, eutrophic lake: implications for the stability of macrophyte-dominance. Freshwater Biol. 55:565-583.

Scheffer M, Carpenter S, Foley JA, Folke C, Walker B, 2001. Catastrophic shifts in ecosystems. Nature 413:591-596.

Schwarz AM, Howard-Williams C, Clayton J, 2000. Analysis 
of relationships between maximum depth limits of aquatic plants and underwater light in 63 New Zealand lakes. New Zeal. J. Mar. Fresh. 34:157-174.

Siemińska J, Bąk M, Dziedzic J, Gąbka M, Grygorowicz P, Mrozińska T, Pełechaty M, Owsianny P, Pliński M, Witkowski A, 2006. [Red list of the algae in Poland, p. 3752]. In: Szafer Institute of Botany (ed.) [Red list of plants and fungi in Poland].[Book in Polish]. Polish Academy of Science, Kraków.

Søndergaard M, Phillips G, Hellsten S, Kolada A, Ecke F, Mäemets H, Mjelde M, Azzella MM, Oggioni A, 2013. Maximum growing depth of submerged macrophytes in European lakes. Hydrobiologia 704:165-177.

Stella E, 1951. [Il lago di Albano. Parte II. Le società litorali].[Article in Italian]. Boll. Pesca Piscic. Idrobiol. 6:23-53.

Stelzer D, Schneider S, Melzer A, 2005. Macrophyte based assessment of lakes - a contribution to the implementation of the European Water Framework Directive in Germany. Int. Rev. Hydrobiol. 90:223-237.

Stewart N, Church J, 1992. Red Data Books of Britain \& Ireland: stoneworts. JNCC: $144 \mathrm{pp}$.

Tartari G, Buraschi E, Monguzzi C, Marchetto A, Copetti D, Salerno F, Previtali L, Tatti S, Barbiero G, Pagnotta R, 2004. [Progetto LIMNO: qualità delle acque lacustri italiane. Vol.
1: sintesi dei risultati].[Article in Italian]. Quaderni Istituto Ricerca sulle Acque 120:334. Accessed on: 2 November 2013. Available from: http://www.ise.cnr.it/limno/

Temniskova D, Stoyneva P, Kirjakov K, 2008. Red List of the Bulgarian algae. I. Macroalgae. Phytol. Balc. 14:193-206.

Tomasella M, Oriolo G, 2006. [Primo contributo alla conoscenza delle Characeae del Friuli Venezia Giulia e dei territori limitrofi: il genere Chara L.].[Article in Italian]. Gortania: 28:109-122.

Troia A, Azzella MM, 2013. Isoëtes sabatina (Isoëtaceae, Lycopodiophyta), a new aquatic species from Central Italy. Plant Biosyst. 147:1052-1058.

Trotter A, 1908. [Laghi di monticchio - introduzione, considerazioni generali, sguardo botanico, cenni sulla morfologia fisica e sulla biologia]. [Article in Italian]. Annal. Bot. 11:1-30.

Vellak A, Tuvi EL, Reier U, Kalamees R, Roosaluste E, Zobel M, Pärtel M, 2009. Past and present effectiveness of protected areas for conservation of naturally and anthropogenically rare plant species. Conserv. Biol. 23:750-757.

Vestergaard O, Sand-Jensen K, 2000a. Alkalinity and trophic state regulate aquatic plant distribution in Danish lakes. Aquat. Bot. 67:85-107.

Vestergaard O, Sand-Jensen K, 2000b. Aquatic macrophyte richness in Danish lakes in relation to alkalinity, transparency, and lake area. Can. J. Fish. Aquat. Sci. 57:2022-2031. 